\title{
The Essence of the Regional Head Election System in Realizing Clean Government in Indonesia
}

\author{
Andi Bau Mallarangeng $^{1 *} \quad$ Achmad Ruslan $^{2} \quad$ Muhammad Djafar Saidi ${ }^{2} \quad$ Anshori Ilyas $^{2}$ \\ 1.Doctoral Student, Faculty of Law, Hasanuddin University, Indonesia \\ 2.Professor of Law, Faculty of Law, Hasanuddin University, Indonesia
}

\begin{abstract}
Indonesia is a unitary state in the form of a Republic. It government system is based on regional autonomy model. The electoral system is held in democratic ways through both representatives and direct elections. One of the main problems in regional head election is that the direct election model raises a variety of problems, especially related to corruption and conflicts in society. This article objectively assesses the importance of the construction of regional head election system based on legal and democratic values, so that it can eliminate corruption and horizontal conflicts to create clean government in Indonesia.
\end{abstract}

Keywords: Regional Head Election, Rule of Law Values, Democratic Values

DOI: $10.7176 /$ JLPG/85-26

Publication date:May $31^{\text {st }} 2019$

\section{Introduction}

Indonesia as a democratic country, fundamentally recognizes and guarantees that sovereignty in its essence belongs to the people. This is reflected in Article 1 paragraph (2) of the Constitution of the Republic of Indonesia (hereinafter written the 1945 Constitution of the Republic of Indonesia) that sovereignty is in the hands of the people, and is carried out according to the Constitution. The sovereignty of the people means that the administration of state government must be sourced and focused on the interests and will of the people. This means that the will of people through people participation is a fundamental factor in the administration of government. The implementation of people sovereignty cannot be separated from general election because election is a logical consequence that adopts the principle of people's sovereignty (democracy) in the life of the people and of the nation. The basic principle of democratic state is that every citizen has the right to participate actively in the political process (Dahlan Thaib 1993).

According to Ramlan Surbakti, there are three basic objectives of the election. First, as a mechanism for selecting government leaders and as an alternative of public policies. In democracy, people's sovereignty is highly upheld that it is known as the spirit of the people, by the people, and for the people. In a democratic system, the people's representatives have full sovereignty but the implementation is performed by their representatives through a representative institution or parliament. Not just anyone can be a people's representative. Someone who has a very strong economic or cultural authority cannot be a people's representative without adequate morality, integrity, and accountability. Therefore, general election is held as a mechanism for selecting and delegating sovereignty to people or parties.

Second, election is also a mechanism to transfer conflicts of interest from the public to people representative institution through the elected representatives or parties that win seats, so that people's integration or unity is guaranteed. The benefits of this election are related to the assumption that the community has different and even conflicting interests, and the conflicts should be resolved through a process of deliberation.

Third, election is a means of mobilizing people's support for the political process. This aspect is increasingly urgent, because people have experienced a kind of alienation from the policy making process or there is a wide gap between the policy-making process and the interests of the elite with grassroots level aspirations which at any time can encourage doubt on the political parties and government. (Ramlan Surbakti, 1992).

The idea of one of the basic objectives of holding direct regional election is that the creation of effective regional government requires in-depth research to help put scientific ideas about the electoral system and the ideal regional head election model that will produce a good goverment.

\section{Rule of Law Values}

In implementing a government system, there is a process of obtaining power, both in the legislative and judicial contexts carried out through electoral mechanisms in which there are practical political principles. Political principles are needed by political parties in carrying out practical political processes. In practicing politics, we must understand the values and legal norms in accordance with the prevailing laws and regulations to accommodate the interests of the people in order to create a good political practice that does not conflict with legal norms. (Ronny Winarno 2015).

Gaining power in a government system in general is carried out by holding a general election. In a modern country, the term of Pemilu or general election is well known because one of the substances of the state system 
existence is to periodically organize general election in order to determine the leadership of a government. Election technically has a very thick nuance of political practice, because it involves the succession of state leadership as a political organization that is given the power to carry out the functions of governing, making rules and implementing the law. The nuance of power as the main achievement in the election makes this procession full of practical political interests.

The essence of practical politics related to power in the government system is assumed and interpreted as having a significant relationship with ways of obtaining legislative power and executive power. The linkage of this relationship is reflected in conflicting condition and situation between political interests and methods taken (political approach), which is carried out in order to realize what is aspired to in the domain of political parties. In this case, the methods adopted in the context of politics are based on the constitutional foundation Article 18 paragraph (3) of the 1945 Constitution of the Republic of Indonesia (hereinafter abbreviated as the 1945 Constitution) will produce power that can greatly affect the implementation of the government system (Ronny Winarno 2015).

Practical politics cannot be separated from legal values and norms as a guideline in politics and as a frame to resolve various political problems that will always accompany political progress and political behavior. Therefore, the position of legal values and norms must be complemented by strict legal norms and policies and include the substances of legislation establishment or law-making process, implementation, and law enforcement. In this context, an understanding of the importance of rule of law values in the implementation of election is part of the nuance of practical politics, urgent to occupy.

The rule of law as a concept with regard to the existence of a modern political organization, in this case is the state, which is known as an idea that the organization of society (state). As a system of administering a government, it must stand on an orderly nature, namely law. State as defined by Iver in I Gede Atmaja: The state of all conceptions and functions and systems originates from the Lan language, namely 'lo stato' which means: the whole permanent position, officials in their positions, rulers and followers, and controlled territory. Iver stated that the meaning of state was a controversy among experts. The controversy views a state as a class structure that controls other classes, some said that a state is defined as a system of power and a system of welfare. Some also said that a state is a legal construction, then there are those who think that a state is the same as a nation, while others said that a state is identical with nationality. (Iver in I Dewa Gede Atmadja 2012).

Meanwhile, Socrates provides an overview of the meaning of state, namely an objective arrangement based on the nature of human nature. Therefore, state has the duty to implement and apply objective laws containing justice for the people and not only serve the needs of changing state authorities. (Anggriani 2012). A state is not an organization that only emphasizes the life of its organization, but one of a state's duties is to establish, undergo, and give a sense of justice to all people with the principle of service for the people as state power holders for shared needs and expectations, with full sovereignty which is accumulated to the public in general. The state organizer is the ruler of the state owner, which is the people with all inherent sovereignty become an implication that obliges public officials to maximize their position in the people's interests. (Hayat 2015).

Indonesia is a modern country in the form of a republic. The operationalization of the state is based on a constitution as a basic law called the 1945 Constitution. Therefore, the state of the Republic of Indonesia can be called a state based on law, because legal norms have become the main requirement for the holding of state power. The material in the 1945 Constitution contains values, rules, and norms that substantially contain guidelines and directives for the national development process, especially the development of the legal sector (Muhtamar 2016). The development of this law is also related to how to construct the electoral system nationally, so that it becomes a guideline for the implementation in national and regional leadership.

On the other hand, legal terms are also important to understand in relation to the state concept. This can be seen in what the theory of Lon Fuller stated in Dimya and Wardiono emphasizing the contents of positive law which must fulfill eight specific moral requirements, among others (Fuller in Khudzaifah and Wardiono 2007): First, there must be rules as guidelines for decision making. Law is a configuration of decisions taken as a concrete step in its application fairly and wisely in accordance with legal rules. Second, the rules that guide the authority must not be kept secret, but must be announced. Rules as a guideline in performing an action become a joint right to be known and socialized, so that it can be understood together to shape a similar perception to the development of a paradigm conceptually and transparently toward the existing rules, so that the power of the rules emphasizes the understanding that will not automatically violate the existing rules. Third, the rules must be made to guide future activities. Law is a rule that becomes a guideline in performing the prevailing rights and obligations at this time with non-retroactivity conception. Fourth, the law must be made in such a way that it can be understood by the people. Hierarchically, people have the right to know, comprehend, and understand the applicable rules of law in society. However, people often become apathetic about the existing rules, except those who are directly related. Fifth, the rules may not conflict with each other. The existence of rules is made to regulate people's lives, so that they are systematized and well-structured for all forms of action in people's lives. Sixth, the rules may not require behavior beyond the ability of the parties bound in it. Every human being has limited abilities in their lives 
according to the nature that God has bestowed with various shortcomings and limitations they have. Of course, humans will act and obey according to their abilities. Rules become a limiting-value in human life between bad and good, but the restriction must be accompanied by sanctions. Seventh, the law must be firm. Law becomes an absolute rule that must be obeyed by every person, whoever violates it must be sanctioned in accordance with the applicable provisions. The law has formal legality values with strict sanctions. Eighth, there must be consistency between the rules as announced with the implementation in the reality.

Therefore, in the application of the rule of law principles in terms of the holding of election in the context of regional head election, it must refer to the place where the election is held. In this case, the Indonesian nation itself. The Indonesian nation in the rule of law establishment was based on the ideals of the law (rechtsidee) of Pancasila. Regarding the rule of law concept based on Pancasila, Hasan Zaini stated that: "The basis of the rule of law according to Pancasila is based on the recognition of the existence of divine law, natural law, and ethical law. In addition, the position and relationship of three types of laws can be drawn up between one another and the state as well as positive law in one framework" (Arumadi and Sunarto1990).

In order to realize the ideals of the rule of law of Pancasila, then life in a rule of law must be regulated in the Constitution. Constitution and rule of law cannot be separated from each other. The Constitution is the main warantee to protect the people from ill-treatment. Thus, the constitutional state concept arises, in which the Constitution is considered as the most effective institution to protect the people through the rule of law or rechtsstaat concept.

To gain a complete understanding of the rule of law of Pancasila, it must be seen and explored into the process and background of creation of the Preamble of the 1945 Constitution formulation as a statement of the will of the birth of Indonesian state as well as the philosophical basis and purpose of the state. From this research and understanding, we will come to the conclusion that the concept of the rule of law of Pancasila law state is not only having similarities but also has differences with the concept of Western rule of law or rechtstaat.

The position of God in the rule of law of Pancasila is one of the main elements, even it is the "prima causa" according to Oemar Seno Adji. The importance of the Godhead principle in the Indonesian state places the principle of the One Godhead, as the first principle of the foundation of the Indonesian state. The importance of the basis of Godhead when it was formulated by the founding father of our country can be read in Sukarno's speech on June 1, 1945, when talking about the state foundation (philosophische grondslag) which stated: "The Principle of Godhead! It is not only the Indonesian people believing in God, but each Indonesian people should be believing in God. Our faith respectively. Christians worship God according to the instructions of Jesus Christ, Muslims worship according to the instructions of Prophet Muhammad S.A.W, Buddhists worship according to their holy books. Let us all believe in God. The Indonesian state should be a country in which the people can worship freely. All the people should believe in God. Culturally, with no "religious selfishness", and the Indonesian state should be a country believing in God" (Yamin 1959).

\section{Human Rights Protection Values}

The values of human rights as universal values have received respect throughout the constitutions of modern countries. The urgency of human rights in political and legal life has a high level, especially because of the facts in the history of power in the past, in which when the system of state power was still carried out in tyrannical and feudalistic characteristics, it affected the people in the power scope. Therefore, this encourages modern society to increasingly place human rights values as fundamental in both social and political systems and law in modern society.

The right to vote and be elected is the constitutional rights of citizens that have equal rights in law and government as guaranteed by the 1945 Constitution. As a constitutional right, the warantee of the implementation of these rights is regulated in the Law relating to the election of legislative members, the election of the President and Vice President, and election of regional head. The right arrangement is between two paradigms which are mutually resisting. The formulation of legislation set off from paradigm that these rights must be limited, including by using objective reasons to produce public officials with integrity and fair elections. Through the process of constitutional review, the intended paradigm was shifted towards eliminating such restrictions, because it was considered to violate the constitutional rights of the people. The shift has implications for the presence of election legislative products that tend to be more liberal, in which the restrictions on voting rights can only be performed based on incompetence reason. While other aspects which are considered as restriction to produce professional political officials and not legally defective may not be adopted as reasons for restriction. Therefore, the candidate who will be elected, has a moral/legal defect or not, depends on the voters holding the voting rights. Law as a legal product can no longer be used as an instrument to screen candidates for political officials elected through election (Fahmi 2017).

This is a separate problem with regard to the substance of human rights values in an election regulation, especially in the country where the rights to vote and be elected also experience a shift in value throughout the history of regulations governing electoral in Indonesia. This can be said to be inseparable from the context of social 
changes of the people, both nationally and especially internationally. The change in the international community is actually more dominant in the effect on the national political life. Therefore, for instance, changes in the rights values of voting and being elected tend towards liberalism than the typical style of Pancasila ideology of the Republic of Indonesia.

Therefore, it is important to look again at the urgency of protecting human rights in the context of election in the land, especially in the case of regional elections at Provincial as well as Regency and City levels, which of course the reference is the Constitution of the Republic of Indonesia. Citizen rights that are governed by the state include (a) Rights to live; (b) Rights to have a family and reproduce; (c) Rights to develop self; (d) Rights to obtain justice; (e) Rights to personal freedom; (f) Right to security; (g) Rights to welfare; (h) Rights to participate in government; (i) Women's rights; and (j) Children's rights. On point (h), the State clearly recognizes every citizen to participate in the government, namely the political rights, including rights to vote and be elected.

The rights to vote is basic rights of every individual or citizen that must be guaranteed by the State. Provisions related to this matter are regulated in Article 1 paragraph (2), Article 2 paragraph (1), Article 6A (1), Article 19 paragraph (1), and Article 22C (1) of the 1945 Constitution. The formulation of a number of articles is clear that there is no justification for the discrimination of race, wealth, religion, and descent. The provisions of the 1945 Constitution above point out that the state must fulfill all forms of human rights for every citizen, especially with regard to the voting rights of every citizen in General Election, Presidential Election, and Regional Head Election in Indonesia. These provisions confirm that all forms of legislative products governing election, presidential election, and regional election, specifically regulating citizens' suffrage, should open up the widest possible space for every citizen to be able to apply their rights to vote, because restrictions on citizens' suffrage is one of human rights violations (Sa'duddin 2015).

Meanwhile, the rights to be elected are explicitly stipulated in the 1945 Constitution Article 27 paragraph (1) and (2); Article 28, Article 28D paragraph (3), Article 28E paragraph (3). This regulation confirms that the state must fulfill the human rights of its citizens, especially in the involvement of government to be elected in a Democratic Party event including election, presidential election, and regional election. The International Covenant On Civil And Political Rights (ICCPR 1966) deals with the political rights of citizens emphasizing in Article 25 that "Every citizen must have equal rights and opportunities without any distinction and without unfair restrictions to participate in performing all public affairs either directly or through freely elected representatives, then to vote and be elected in free periodic elections and with equal and universal suffrage as well as held through the issuance of written and confidential votes that guarantee voters to express their will freely, and to get public services in their own country in general on the basis of equality. The above provisions are intended to emphasize that political rights, to vote and be elected are human rights. Restrictions, irregularities, and abolition of these rights are a form of violation of the citizens' rights."

In a more substantial dimension, this legal framework must still rely on basic human rights principles. The morality of human rights actually lies in the substance of rights which are fundamental to the society and individuals as human beings. The implementation of human rights at a pragmatic level illustrates its ideal sides. Although it is difficult to avoid the possibility of distortion of idealism at the practical level, at least the ideal spirit of human rights must still be represented in the quantity of morality. So that if regulative norms in the electoral law that come into contact with the value of human rights cannot eliminate the ideal value of human rights. Therefore, this normative value should be prepared to avoid certain practical interests that intend to take advantage of the norms.

Related to this, it is interesting to elaborate on John Rawls's theory which can be used to analyze the matters of limiting rights in relation to voting rights and being elected in the context of regional head election regulation in the country. John Rawls in A Theory of Justice stated two principles justice: "First: each person is to have equal rights to the most extensive scheme of equal basic liberties compatible with a similar scheme of liberties for others. Second: social and economic inequalities are to be arranged so that they are both (a) reasonably expected to be to everyone's advantage, and (b) attached to positions and offices open to all" (Rawls 1971).

Therefore, the implementation of elections, in this case is regional head election, must be interpreted as a manifestation of human rights values protection. In some facts, the process of voting the leadership, especially in regional elections is frequently found a type of violation that can be categorized as a violation of human rights. For instance, in the exposure of the National Human Rights Commission (Komnas HAM) regarding findings of human rights violations related to the holding of regional elections: "Less than two months of voting for the Regional Election of 2018 (Nadlir 2018). This phenomenon explains the high potential regarding the possibility of neglecting the human rights dimension in the process of regional head elections, which of course in quality, if leadership present in a government through a process full of violations of the basic rights of citizens as humans, this leadership is ideally problematic in human rights. Therefore, the leadership will fall morally or in the ideal of human rights. 


\section{Democratic Values}

Until now, the democratic system is still the main icon for modern countries, especially the rule of law which places the democratic system as part of determining the purpose of the country's legal politics. On the same side, many countries claim to be democratic countries, but it is far from the democratic values. Indonesia as a democratic state, of course its legality value must be seen in the basic law, in this case is the 1945 Constitution of the Republic of Indonesia. The higher the value of democracy contained in the legality, the stronger the legitimacy possessed. Because in principle, democracy contains good values for society and the state. One of the good values of democracy in Indonesia is implemented through the process of determining the state leaders which is voted by the people. In determining the purpose of legal politics regarding election, the concept of democracy adopted by Indonesia is Pancasila as the main guideline. Because the value in a real democratic system does not stop at the people who determine the leader and state policies, but also in the democratic system it contains a broader value. Secondly, as a country embracing the civil law system, the legal formulation of the general election law is performed by normalization in the basic law, namely the 1945 Constitution of the Republic of Indonesia and other laws and regulations (Zaman 2018).

The basic principles of democracy as the incarnation of the essence of government doctrine from, by, and for the people, which is the norm both in the Constitution and other laws and regulations, can be said as one of the main value bases of holding national leadership election, both at national and regional levels. The values of Democracy which are universally acceptable values in this modern century have become values or dogmas that are inseparable from modern state systems.

The value of the democratic system in Indonesia must be built on the basis of equality in a responsible way. The democracy in Indonesia that is declared through Law No. 7 of 2017 is not good, if the responsibility value of all stake holders has not been clearly seen. The position of the people as the owners of sovereignty must be respected by the parties responsible for formulating norms about elections. In doctrine, people's sovereignty is classified into 2 (two), namely essential principles and procedural principles. The essential principle is proven that the general election is regulated in the 1945 Constitution. The guarantee of human rights in the 1945 Constitution is a manifestation of recognition of the equal position among citizens. The procedural principles of democracy or popular sovereignty are two, at least, namely the principle of the majority of votes and the principle of accountability (Fahmi 2012).

There are two substances that must be achieved in the process of implementing democracy values with regard to the success of leadership, namely essential outcomes and procedural outcomes. In many cases, the procedural aspects are more dominant than the essential aspects in terms of elections and regional elections, frequently. So that procedural or mechanistic success is considered to have fulfilled the essence of democracy. Though in fact the essence of democracy cannot be determined by its procedural achievements, because this concerns the ideal dimension or quality of democracy. If the procedural aspects as the only means of formal legitimacy whose fulfillment has been deemed to have also fulfilled the essence of democratic values, this will further endanger the implementation of democratic conditions in the life of political and legal societies.

The essential aspect of democracy is also related to the background of the birth of democracy idea itself. The concept of democracy, which has been known since the 5th century BC, initially appeared as a response to the bad experience of the monarchical government and the dictatorship of the city states in ancient Greece. The ideas of modern democracy began to develop in the 16th century, namely the development of ideas for secularism initiated by Nicolo Machhiavelli (1469-1527), the idea of a contract state by Thomas Hobbes (1588-1679), ideas about constitution, state and liberalism, and the division of legislative, executive, and federal institutions by John Locke (1632-1756). Then, followed by the idea of the powers' separation into legislative, executive, and judicial institutions by Baron de Montesqueieu (1689-1755) and ideas about popular sovereignty and social contracts permitted by Jean Jacques Rousseau (1912-1778) (Abdillah 1999).

One of the principles of democracy that is no less important in carrying out democracy is freedom. The importance of freedom in democracy is described by Colin Bird, that: A society is not free unless iffollows its own will, and that "its own will" must mean the will of the people who comprise it. Since only democratic procedures can identify the popular will, they are necessary, and perhaps sufficient, conditions for realizing the value of political freedom or self-government, or so the argument maintains (Kuswanto 2016).

The idea implies that a society is not free unless it is able to follow its own will, that is, the will of a collection of people as members of that community. Only democratic procedures that are able to identify the common will of the people, realize the value of political freedom or self-government of the people, a government whose basis is the will of the people's collective. Furthermore, Bird explained that political freedom is very meaningful for citizens. According to Bird, freedom as an idea of self-government collectively is a value that is natural or inherent, and direct for every human being. Conversely, democracy is important as a procedure for maintaining or protecting freedom in dealing with government power.

With regard to the practice of modern democracy in the system of modern countries, it is necessary to consider the ideology of a country. For example, in the Indonesian context, the essence of the general principles of 
democracy which have a liberal tendency, because it is persistent in the social situation in Western civilization, the Pancasila ideology must still be the philosophical basis of democratic practices that will be applied in the Indonesian national life system. This is also because, constitutionally, the values of Pancasila have become the fundamental material of the basis of Indonesian state and life, so it is important to always refer philosophically to the doctrine of Pancasila as the spirit and constitutional of Indonesian people.

According to Darji Darmodiharjo, Pancasila as a source of all sources of law, it contains philosophical values that overshadow any existing legislation. The philosophical values contained in the Pancasila are seen through the moral principles in the Pancasila. Pancasila as the source of all sources of law functions as ideals or ideas. As aspirations, Pancasila should always be endeavored to be achieved by every human being in Indonesia, so that these ideals become reality. Judging from its position, Pancasila has a high position, namely as the ideals and ideology of the people and of the nation. Judging from its function, Pancasila has the main function as the basis of the state. Judging from its material, Pancasila is extracted from the ideology of the Indonesian nation which is the soul and personality of the Indonesian nation. It can be said that Pancasila was created from domestic material, pure original material, and pride for a patriotic nation (Darmodiharjo, et.al 1991).

This position of the Pancasila in the legal political position regarding the election of National and regional leaders should not escape from the Pancasila as the state's ideology. This means that the practice of democracy applied in the electoral system is the implementation of Pancasila values, so the essence of democratic values is manifested in the essence of Pancasila ideological values. So that they have unique characteristics of Indonesia because of their ideological ideology, not liberal democracy.

The implementation of democratic principles in the procession of national leadership succession and especially in the regions, if based on the spirit life in which the community lives, will provide a variety of theoretical guarantees that the practice of democracy in voting leaders is in accordance with the principles of community life, so that there is no feeling like a kind of alienation of values. Suppose for example that democracy based on individualism and/or liberalism is applied in a communal society, just as the characteristics and character of the Indonesian nation will certainly experience a kind of counter-productive with existing basic principles and values and life in the nation's society. Therefore, in the context of modern society, the importance of democratic principles that have universalized is to be applied, so that it must seriously pay attention in its implementation to the ideology that grows in society. So that the power embodied in the democratic procession is something that can be received carefully by the mind and soul of the people, because its value has a close relationship with the value system that they adhere to and understand.

The application of the concept of democracy provides an opportunity for regular and peaceful power rotation. In the sense that elections are conducted regularly with a clear grace period accompanied by competition that is honest, healthy and fair, it must be able to produce quality leaders. Therefore, the implementation of democracy is not only limited to what has been set out in a procedure or mechanism, but also must be carried out in substance by prioritizing the principles of justice, honesty, and openness (Ilmar 2014).

According to Affan Gaffar, there are two kinds of understandings on democracy in politics, namely normative understanding and empirical understanding or commonly called as procedural democracy. In normative understanding, democracy is an ideal to be held by a country, as a phrase "government from the people, by the people, and for the people" (Gaffar 2003).

\section{Conclusion}

The essence of regional head election is to hold someone in the office of state power in a government in the region through a democratic election mechanism. This regional head election is interpreted as an implementation and the realization of people's sovereignty for regional government at the same time, which is held based on the rule of law values, human rights values, and democratic values.

\section{References}

Affan Gaffar, (2003), "Politik Indonesia Transisi Menuju Demokrasi”, Pustaka Pelajar, Yogyakarta.

Bambang Arumadi dan Sunarto, (1990), “Konsepsi Negara Hukum Menurut UUD 1945”, IKIP Semarang Press, Semarang.

Dahlan Thaib, (1993), "Implimentasi Sistem Ketatanegaraan Menurut UUD 1945”, Liberty, Yogyakarta.

Darji Darmodiharjo, et.al, (1991), "Santiaji Pancasila, Suatu Tinjauan Filosofis, Historis dan Yuridis Konstitusional", Usaha Nasional, Surabaya.

I Dewa Gede Atmadja, (2012), “Ilmu Negara: Sejarah, Konsep Negara dan Kajian Kenegaraan”, Setara Press, Malang.

Hayat, (2015), "Keadilan sebagai Prinsip Negara Hukum: Tinjauan Teores dalam Konsep Demokrasi, Jurnal Ilmu Hukum, PADJADJARAN, 2 (2), 383-404.

Jum Anggriani, 2012. Hukum Administrasi Negara, Graha Ilmu, Yogyakarta.

John Rawls, (1971), “A Thery Of Justice (Revised Edition)”, Cambridge,: The Belknap Press of Harvard 
University Press, Massachusetts.

Muhammad Yamin, (1959), "Naskah Persiapan Undang-undang Dasar 1945”, Jilid 1.

Khudzaifah Dimyati dan Kelik Wardiono, (2007), "Pola Pemikiran Hukum Responsif; Sebuah Studi Atas Proses Pembangunan Ilmu Hukum Indonesia”, Jurnal Ilmu Hukum, 10 (1), 1-13.

Khairul Fahmi, (2017). "Pergeseran Pembatasan Hak Pilih dalam Regulasi Pemilu dan Pilkada", Jurnal Konstitusi, 14 (4), Desember, 677-758.

Khairul Fahmi, (2012), "Pemilihan Umum \& Kedaulatan Rakyat”, Raja Grafindo Persada, Jakarta.

Kuswanto, (2016), "Konstitusionalitas Penyederhanaan Partai Politik, Pengaturan Penyederhanaan Partai Politik dalam Demokrasi Presidensial", Setara Press, Malang.

Moh Nadlir, (2018), "Ini Empat Temuan Komnas HAM Jelang Pilkada Serentak 2018”, https://nasional.kompas.com/ (diakses 2 Maret 2019).

Masykuri Abdillah, 1999, Demokrasi dipersimpangan Makna, Respon Intelektual Muslim Indonesia Terhadap Konsep Demokrasi (1965-1993), PT Tara Wacana, Yogyakarta.

Nurus Zaman, (2018), "Implementasi Nilai-Nilai Demokrasi dalam Menentukan Arah Politik Hukum Negara tentang Pemilihan Umum di Indonesia", https://journal.unnes.ac.id/sju/index.php/snh, 4 (3), 667-684.

Ramlan Surbakti, (1992), "Memahami Ilmu Politik, Grasindo, Jakarta.

Ramlan Surbakti, (1992), "Memahami Ilmu Politik, Grasindo, Jakarta.

Ronny Winarno, (2015). “Arti Penting Nilai-Nilai Dan Norma Hukum Dalam Berpolitik Praktis", Jurnal Perspektif, XX (2), 82-79.

Syafruddin Muhtamar, (2016), “Grand Desain Pembangunan Hukum; Arah Pembangunan Sistem Hukum dalam Sejarah Perencanaan Pembangunan Jangka Panjang Nasional Indonesia”, Inti, Makassar.

Sa'duddin, (2015), "Pengaturan Hak Politik Warga Negara”, http://www.dakta.com, (diakses 28 februari 2019). 